\title{
QAR (QUESTION ANSWER RELATIONSHIP) AS AN ALTERNATIVE STRATEGY TO TEACH READING
}

\section{Sa'dulloh Muzammil}

IAIN Pontianak

muzammil@gmail.com

\section{ABSTRACT}

In English language teaching, teaching reading plays an important role, for reading is one of language skills. In order to succeed doing this activity, a teacher must be familiar and able to employ various teaching reading strategies that can assist his/her students comprehend what they read. To check students' reading comprehension, a teacher may propose several questions related to the texts being read. However, if the students have difficulties dealing with these reading comprehension questions, a teacher must be able to help them by introducing reading strategies to overcome the problems. QAR is one of reading strategies which is beneficial for a teacher to check students' reading comprehension and frame reading question-answer activity in reading phases: pre-, while-, and post-reading; as well as to help students locate answers for the questions.

\section{Keywords}

Teaching reading, reading strategy and question-answer relationship

\section{INTRODUCTION}

Teaching reading is not merely intended to enable students understand the meaning of words or recognize new vocabularies of English but comprehend the content of written information or message explicitly and implicitly as well. It suggests that the reader requires good comprehension to obtain message or information from the materials he or she reads. For that, he or she must equip him-/herself with reading skills including mentioning the main idea, getting explicit message, recognizing communicative function, interpreting implicit meaning, and making prediction.

Richard (1996: 164) affirms that comprehension activities may address different levels of comprehension, including literal comprehension 
(understanding meanings stated explicitly in a text), inferential comprehension (drawing conclusions and making predictions based on information in the text), and evaluation (making judgment about the content of a text based on personal or other values). Then, to sustain reading comprehension, the teacher should introduce students with strategies of reading. Richards (2002: 289) purposes the aim of reading strategies as follows:

$>$ Strategies help to improve reading comprehension as well as efficiency in reading.

$>$ By using strategies, students will be reading in the way that expert readers do.

$>$ Strategies help readers to process the text actively, to monitor their comprehension, and to connect what they are reading to their own knowledge and to other parts of the text.

In other word, it can be concluded that the strategies of reading help students to improve their performance on test of comprehension and recall.

Consistent with the findings of the National Reading Panel and the RAND Reading Study Group, this panel states that effective adolescent literacy interventions must provide direct, explicit comprehension instruction in which various approaches are used. Specifically the Study Group identified the following instructional factors:

$>$ Comprehension strategies instruction, which is instruction that explicitly gives students strategies that aid them in comprehending a variety of texts;

$>$ Comprehension monitoring and metacognition instruction, which is instruction that teaches students to become aware of how they understand while they read; 
> Teacher modeling, which involves the teacher reading texts aloud, making her own use of strategies and practices apparent to her students;

Scaffolded instruction, which involves teachers giving high support for students practicing new skills and then slowly decreasing that support to increase student ownership and self-sufficiency; and

Apprenticeship models, which involve teachers engaging students in a content-centered learning relationship (2002: 13-14).

Explicit strategy instruction, moreover, may be employed sincestudents need to be taught strategies in a very direct, visible way because explicit instruction provides a clear explanation of the tasks involved in comprehending. It also helps students to pay careful attention to each of the tasks and encourages them to activate their prior knowledge. Explicit teaching also invites the reader to breaks the task into small pieces, and it provides direct, continual feedback from the teacher, (flood, et al. 2006).

The purpose of explicit strategy instruction is to facilitate independent learning. In order to become active, self-directed readers, students must have knowledge of themselves as readers, be cognizant of the strategies they use when deciphering texts, and select appropriate reading strategies and monitor the effectiveness of those strategies (Irvin, 1998 in flood, et al. 2006: 6).

Besides facilitating student with explicit strategy instruction, teacher should enhance students' reading performance standard. One of the efforts is by focusing not only on low level instruction but also high-quality of level instruction of reading comprehension, in order that students can achieve proficiency of reading. Snow (2002: xiii) identifies literacy proficiency is reached when

a reader can read a variety of materials with ease and interest, can read for varying purposes, and can read with comprehension 
even when the material is neither easy to understand not intrinsically interesting....proficient readers...are capable of acquiring new knowledge and understanding new concepts, are capable of applying textual information appropriately, and are capable of being engaged in the reading process and reflection on what is being read.

It suggests that students should read materials easily and interestingly with good comprehension even though the materials they read are difficult or easy and absorb new knowledge and understand new concept. They must also be able to reflect what is being read and think critically.

In order to know whether students comprehend what they read, teacher can ask them to answer reading comprehension questions. It may be an indication that students have low ability of reading if then they cannot answer many questions correctly. Besides, traditionally, having students answer teacher-created questions has been an accepted practice for guiding as well as assessing student comprehension. Research evidence indicates that teacher questioning may best be used as part of a multiple-strategy instructional program (National Reading Panel, 2000; Stahl, 2004) in Irwin, (www.PeoplesEducation.com, September, 29 $9^{\text {th, }}$ 2009). According to Raphael (1982: 182) "when students have difficulty answering questions, we often assume it is because they have not read carefully. However, it may actually be that they need to be taught how to analyse a question in order to find the correct answers"

Consequently it cannot be accepted if English teacher does following steps: the teacher asks students to read a text, check student's vocabulary and pronunciation. He/she then administers reading comprehension test without providing the student comprehension strategy. The teacher's technique to teach reading makes the students get bored and less motivated to join the instructional activity. Besides, the fact that the students' reading 
comprehension is low can be associated with students less recognizing how to find the answer of comprehension questions. The students often assume that the answer of every question can only be found in the text, whereas, the answer of questions, sometime, can only be found in the readers' head (http://www.greece). Question of making prediction is the example of the question in which the answer can be found in the readers' head.

Considering the reasons above, the writer is interested in implementing a strategy of comprehension proposed by Rafael (1986: 516-521): questionanswer relationships (QAR). The strategy is aimed at improving students reading comprehension skill. It helps students realize that the answers they seek are related to the type of question that is asked; it encourages them to be strategic about their search for answers based on an awareness of what different types of questions look for. Even more important is understanding where the answer will come from.

QAR comprises two board categories: "In the Book" that includes question of "Right There" and "Think and Search" and "In my Head" that comprehends question of "On My Own" and "Author and You". They are explained as follows:

"Right There" is questions require readers to go back to the passage and find the correct information to answer the question. These are sometimes called literal questions because the correct answer can be found somewhere in the passage. "Right There" questions sometimes include the words "According to the passage..." "How many..." "Who is..." "What is..."

"Think and Search" is questions usually require readers to think about how ideas or information in the passage relate to each other. Readers need to look back at the passage, find the information that the 
question refers to, and then think about how the information or ideas fit together. "Think and Search" questions sometimes include the words "The main idea of the passage..." "What caused..." "Compare/contrast..."

"On My Own" is questions can be answered using readers' background knowledge on a topic. This type of question does not require readers to refer to passage. "On My Own" questions sometime include the words "In your opinion..." "Based on your experience..." "Think about someone/something you know..."

"Author and You" is questions require readers to use ideas and information that is not stated directly in the passage to answer the question. These questions require you to think about what you have read and formulate your own ideas or opinions. "Author and you" questions sometimes include the words "The author implies..." "The passage suggests..." "The speaker's attitude..." (http://www.greece.k12.ny.us/ instruction/ela/6-12/Tools/Qar.pdf, July 19, 2016).

By categorizing the questions into generally two categories: "In the Book" and "In my Head", it is hoped that students will be much easier to answer questions. They do not, for instance, consume too much times just to find answer that do not belong to "Right there" since they assume that every question's answer is directly stated somewhere in the text, if only they look hard enough.

Essentially, QAR teaches students three comprehension strategies: (a) locating information, (b) determining text structures and how they convey information, and (c) determining when an inference is required (Raphael, 1986). Using QAR, students will be able to recognize possible answer 
locations by classifying questions by type as well as monitor their comprehension of the text. Furthermore, by implementing QAR, students are stimulated to think critically as the technique involves high-quality level of questions. In addition, according to Wilson, et al. (2009: 710) the QAR framework was chosen for the professional development initiative because a common practice for students to be asked to respond to questions in the text. QAR gives a framework for thinking about these questions and provide students with the tools and language for identifying the relationships between text and questions. QAR cannot only guide classroom reading discussion but also assist students in becoming more strategic, or metacognitive, in their reading.

\section{DISCUSSION}

\section{The Notion of Question Answer Relationship (QAR)}

Raphael (1986: 516) developed QAR as a tool for clarifying how students can approach the task of reading texts and answering questions. It helps them realize the need to consider both information in the texts and information from their own background knowledge.Without QAR instruction, students often over rely on text information or background knowledge. Furthermore, Corner (2006) states that QAR is reading strategy in which students categorize comprehension questions according to where they got the information they needed to answer each question. Students are asked to indicate whether the information they used to answer questions about the text was textually explicit information, textually implicit information, or information entirely from the student's own background knowledge. 
In addition, Stahl (2005: 601) states that 'the questions that teachers ask and instruction in QAR or other teacher-led questioning can act as a springboard and a model for critical thinking and complex student generated questions. Teacher-led questioning can be a powerful vehicle in moving text interactions toward higher levels of thinking and critical literacy'. It suggests that QAR is beneficial to providing students with higher-level questions in order that students can improve their level of critical thinking and literacy.

According to Rafael and Au (2005: 208) QAR can help to solve four problems to enhance students' level of literacy:

The need for a shared language to make visible the largely invisible processes underlying reading and listening comprehension.

$>\quad$ The need for a framework for organizing questioning activities and comprehension instruction within and across grades and school subjects.

$>$ The need for accessible and straight forward whole-school reform for literacy instruction oriented toward higher level thinking.

$>$ The need to prepare students for high-stakes testing without undermining a strong focus on higher level thinking with text. Conner (2006) affirms that QAR serves five primary purposes:

$>$ Help students monitor their comprehension of the text.

$>$ Provides a purpose for reading the text.

$>$ Allows students to assess their comprehension of the text.

$>$ Encourages elaborative and critical thinking.

$>$ Helps refute the common misconception held by students that the text tells all. http://www.indiana.edu/ 1517/QAR.htm.June, 13, 2009.

By employing QAR it is hoped that teacher can help students improve their reading comprehension since QAR provides students with question- 
answer strategies of reading comprehension. The categories of question provided in QAR enable students to consume much less time. http://www.greece.k12.ny.us/instruction/ela/6-2/Reading/Reading\%20 strategies /QAR.htm, July, 20, 2009).By using QAR, students need not to spend their many times looking at reading passage in order to find answer that belong to 'In My Head' question as the question needs students to answer the question by using their background knowledge or schemata.

\section{QAR Categories}

Raphael (1986: 518-519) identified two board categories of QAR for finding information and for answering questions: first category is In the book questions consisting of Right there and Think and Search questions. These questions require answers that can be found directly in the text. Another category is In your head questions consisting of Author and you and On your own. These questions require a higher level of thinking. While details from the text may or may not be used, the primary source of the answer will involve the reader's own thinking in relation to the text, the author's meaning, and application of the theme outside the text.The details of both categories are described as follows:

\subsection{In The Book Questions}

\subsubsection{Right There}

Right there questions require reader to go back to the passage and find the correct information (explicit information) to answer the questions. These are sometimes called literal question as the correct answer can be found in the passage. Right there questions sometimes include the words: According to the passages, How many, Who is, Where is, and What is. 
The steps may be purposed to answer Right There questions are as follows:

- Reread

- Scan

- Look for key words

\subsubsection{Think and Search}

In Think and Search questions, the answer will still be in the text, but the details necessary to answer the questions may be in more than one location. The questions usually require the reader to think about ideas or information (implicit information) in the passage relate to each other. To answer the questions effectively, the reader will need to "think and search" throughout the text and will need to look back at the passage, find the information that the question refers to and then think about how the information or ideas fit together.

The steps may be purposed to answer Think and Search questions are as follows:

- $\quad$ Skim or reread

- $\quad$ Look for important information

- Summarize

\subsection{In Your Head Questions}

\subsubsection{Author and You}

Author and You questions require reader to use ideas and information that is not stated directly in the passage to answer the question. These questions require the reader to think about what you have read and formulate your own include the words: The author implies, The passage suggests, and The speaker's attitude. 
The steps may be purposed to answer Author and You questions are as follows:

- Reread

- Think about what you already know and what the author says

- Predict

\subsubsection{On Your Own}

On Your Own questions can be answered using reader's background knowledge on a topic. This type of questions does not usually appear on tests of reading comprehension because it does require the reader to refer to the passage. On Your Own questions sometimes include the words: In your opinion, Based on your experience, and Think about someone/something you know.

The steps may be purposed to answer On Your Own questions are as follows:

- Think about what you already know

- Think about what you have already read before

- Make connection

Explaining QAR to students, Raphael and Pearson (1985: 220) purpose the following mnemonics:

(1) Right There meant that words used to create the question and words used for the answer are "right there" in the same sentence. (2) Think and Search meant that the answer is in the text, but words used to create the question and those used for an appropriate answer would be found in two or more sentences; you would have to "think and search" for an answer across sentences and paragraphs. (3) On My Own meant that the answer is not found in the text: rather, you would think to yourself that "I have to find this answer 'on my own'. 
The same mnemonic of On My Own can be generalized for Author and $\mathrm{Me}$ as it is also meant that the answer can be found beyond the text. Therefore, it requires the reader to make use his or her head for the answer. But Raphael later modifies "Right There" cannot only be used in the same sentence but also can be used in two sentences related by pronoun.

\section{Procedure to Teach QAR}

Based on Raphael's recommendations (1986: 518-519), the difference between in the book and in the head responses were discussed before discriminating between the two text-based question types. Following the introduction and modeling, a short passage is read with questions for which the answer as well as the type of QAR each question represented is identified and discussed. In the second stage, a parallel task involving another short passage is read whereby questions and answers are provided and students generate as a group the QAR for each. Finally, in the third stage, students determined the QAR and respond with answers to questions based on a longer passage. The maintenance activities based on the basal are used to provide students with further guided practice as they read longer passages. During these activities, students work in group learning. Group learning is used considering QAR involves higher-level questions. According to Aebersold\& Field (1997: 123)

Higher-level questions can be frustrating for some students; teachers should plan their use carefully. Students benefit greatly from the thoughts, experience, and knowledge of their classmates, and small group discussions of higher-level questions may be last threatening and most helpful way to introduce this level of work. 
During the class discussion, students need to justify their answer to the question and their choice of a QAR and the teacher explained why it is acceptable on the grounds of both accuracy and strategy.

The QAR framework below was used to frame the following teacher modeling of question-asking practices during the reading cycle (adapted from Raphael \& Au, 2005).

Table I

The QAR framework

\begin{tabular}{|c|c|c|c|}
\hline $\begin{array}{l}\text { Reading } \\
\text { Cycle }\end{array}$ & QAR & $\begin{array}{l}\text { Comprehension } \\
\text { Strategies }\end{array}$ & Questions \\
\hline \multirow[t]{2}{*}{$\begin{array}{l}\text { Before } \\
\text { reading }\end{array}$} & $\begin{array}{l}\text { On My } \\
\text { Own }\end{array}$ & $\begin{array}{l}\text { Activating prior } \\
\text { Knowledge }\end{array}$ & $\begin{array}{l}\text { From the title, what do I } \\
\text { already know that can } \\
\text { connect me to the text? }\end{array}$ \\
\hline & $\begin{array}{l}\text { Author \& } \\
\text { Me }\end{array}$ & $\begin{array}{l}\text { Predicting } \\
\text { Visualizing }\end{array}$ & $\begin{array}{l}\text { From the title or illustrations, } \\
\text { what might this text be about? }\end{array}$ \\
\hline \multirow{3}{*}{$\begin{array}{l}\text { During } \\
\text { reading }\end{array}$} & $\begin{array}{l}\text { Author \& } \\
\text { Me }\end{array}$ & $\begin{array}{l}\text { Making simple } \\
\text { and complex } \\
\text { inferences }\end{array}$ & $\begin{array}{l}\text { What do you think will } \\
\text { happen next? } \\
\text { How would I describe the } \\
\text { mood of the story and why is } \\
\text { this important? }\end{array}$ \\
\hline & $\begin{array}{l}\text { Right } \\
\text { There }\end{array}$ & $\begin{array}{l}\text { Scanning to } \\
\text { locate } \\
\text { information }\end{array}$ & $\begin{array}{l}\text { Who is the main character? } \\
\text { What are some words that } \\
\text { describe the setting? }\end{array}$ \\
\hline & $\begin{array}{l}\text { Think \& } \\
\text { Search }\end{array}$ & $\begin{array}{l}\text { Summarizing } \\
\text { Clarifying } \\
\text { Making simple } \\
\text { Inferences }\end{array}$ & $\begin{array}{l}\text { What is the problem and how } \\
\text { is it resolved? } \\
\text { What are the important } \\
\text { events? } \\
\text { What role do the characters } \\
\text { play in the story? }\end{array}$ \\
\hline \multirow[t]{2}{*}{ After reading } & $\begin{array}{l}\text { Author \& } \\
\text { Me }\end{array}$ & $\begin{array}{l}\text { Distinguishing } \\
\text { fact and opinion }\end{array}$ & $\begin{array}{l}\text { What is the author's message? } \\
\text { How well does the author } \\
\text { make his argument? }\end{array}$ \\
\hline & $\begin{array}{l}\text { Think \& } \\
\text { Search }\end{array}$ & $\begin{array}{l}\text { Identifying } \\
\text { important }\end{array}$ & $\begin{array}{l}\text { Find evidence in the text to } \\
\text { support an argument. }\end{array}$ \\
\hline
\end{tabular}




\begin{tabular}{|l|l|l|l|}
\hline & & information & \\
\hline
\end{tabular}

\section{The Advantages and the Weaknesses of QAR}

The four QARs provide a useful framework for teachers and students. First, when students are consciously aware of the different sources of information available to answer questions, they become strategic in their reading and thinking, and their comprehension is improved. Second, the four QARs are helpful in teacher planning. Teachers need to strike a better balance between literal questioning and higher level questioning. Questions reflecting the Think and Search, Author and You, and On Your Own help students see relationships, connections, associations between text and prior knowledge, experience, and/or other ideas in the subject area. Such questions often have more than a single word answer, which stimulates students to think rather than wait to be told the "right" answer. (http://shouteastarchoaching.pbworks.com, October, 30, 2009).

In addition, Rafael and $\mathrm{Au}$ (2005: 218) state that QAR addresses four troubling problems of practice today, particularly involving students who often receive little literacy instruction oriented to promoting high levels of thinking about text. First, QAR can help address the lack of a shared language among teachers and students for improving questioning practices, whether in the day-to-day life of the classroom, in students' activities outside of school, or in high-stakes testing situation. Second, QAR can bring coherence to literacy instruction within and across grade level by providing a framework for a developmental progression for comprehension instruction. As a framework, QAR provides a means for organizing comprehension strategy instruction. Third, QAR provides a focal point to begin sustained efforts for whole-school reform aimed at higher standards for literacy 
learning and teaching. It is difficult to find points of contact that bring teachers from kindergarten through middle school to the table with the same high levels of interest. Yet all readers at all grades can benefit from learning to think in terms of information sources for answering and asking questions. Forth, QAR provides a responsible approach to preparing students for highstakes test at different grade levels and in a variety of subject areas, without detracting from the high-quality instruction that leads to high levels of literacy.

However, Credence (2006) raised two concerns with using QAR. Firstly, QAR was intended to describe question-answer types rather than to facilitate the determination of the correct responses. It is therefore not advisable to tell students that the answer to the question is forthcoming from such discrete categories as text or reader'. Secondly, he argues that determining the nature of the question answer relationship logically follows the answering of the question, rather than preceding it. He purports that QAR can only be best regarded as a monitoring tool to help readers achieve feedback on their responses rather than help answer the questions. Despite his concerns, Credence (2006) pointed out that the National Reading Panel (2000) has endorsed QAR as an effective means of improving comprehension.

\section{CONCLUSION}

Research evidence indicates that teacher questioning may best be used as part of a multiple-strategy instructional program (National Reading Panel, 2000; Stahl, 2004). Furthermore, Question-answering instruction can help students get more from their reading by showing them how to find and use information from a text to answer teacher's questions (Levin \& Pressley, 
1981 in Lehr \& Osborn, 2005). Learning question-answering strategies can also help students locate information in a text that is related to the question. (Lehr \& Osborn, 2005).

Having too much difficulty answering question in a such reading activity can be associated with reader's less recognizing how to find the answer of comprehension questions. Consequently, the students need helping to solve the problem by using a reading strategy. According to Richards (2002: 289) reading strategies entail several functions: (1) Strategies help to improve reading comprehension as well as efficiency in reading, (2) By using strategies, students will be reading in the way that expert readers do, (3) Strategies help readers to process the text actively, to monitor their comprehension, and to connect what they are reading to their own knowledge and to other parts of the text. For such reasons, QAR as a comprehension strategy may be proposed to help students improve their reading comprehension.

According to Rafael and Au (2005: 208), QAR can help to solve four problems to enhance students' level of literacy: (1) The need for a shared language to make visible the largely invisible processes underlying reading and listening comprehension, (2) The need for a framework for organizing questioning activities and comprehension instruction within and across grades and school subjects, (3) The need for accessible and straight forward whole-school reform for literacy instruction oriented toward higher level thinking, (4) The need to prepare students for high-stakes testing without undermining a strong focus on higher level thinking with text.

Moreover, Conner (2006) affirms that QAR serves five primary purposes: (1) Help students monitor their comprehension of the text, (2) Provides a purpose for reading the text, (3) Allows students to assess their 
comprehension of the text, (4) Encourages elaborative and critical thinking, (5) Helps refute the common misconception held by students that the text tells all (http://www.indiana.edu/ 1517/QAR.htm. June, 13, 2009).

Question answer relationship (QAR) is a strategy of reading comprehension aimed at assisting students to enhance their reading comprehension. Raphael (1986: 521) says that QAR can be useful both as a teacher tool for conceptualizing and developing comprehension questions and as a student tool for locating information and making decisions about use of the text and background knowledge.

As a tool for teachers, the QAR categorization creates a way of thinking about types of questions that are most appropriate for different point in guiding students though a story. Considering QARs within a general comprehension framework is useful.

As a tool for students, QAR instruction can provide the basis for three comprehension categories: (1) locating information, (2) determining text structures and how these structures may convey information, and (3) determining when an inference would be required or invited. Understanding QARs initially helps the students understand that information from both texts and their knowledge base and experiences is important to consider when answering question.

QAR procedure is based on a three-way relationship among the question, the text, and the reader's prior knowledge. The procedure help students learn to focus on the way that questions are written, and so helps them identify and make distinctions among the sources of information they can use to answer questions. The procedure follows gradual-release model of instruction, moving from entirely teacher directed to entirely student directed. 
The strategy of QAR, moreover, requires students to apply reading strategies: scanning and skimming, to answers Right There and Think Search questions and stimulates students to think critically to what they read by answering questions of Author and you and On Your Own. The questions of the last type encourage students to activate their prior knowledge and schemata and employ their ideas or opinion to answer the questions.

When both students and teachers understand the terms associated with QARs, they have a language that supports both asking and answering questions in a range of classroom contexts. QARs can be used to clarify expectations, such as a teacher stating, "Well, you are asking each other a lot of 'Right There' questions in your discussions, but I was hoping you would use more 'Author and Me' and 'Think and Search' ones." It can be used to promote discussion in book clubs or literary circles, such as an assignment that asks students to come to group with at least one "Author and Me" and one "On My Own" question for the others in their group.

Meanwhile, teaching students through the QAR strategy requires more than just an awareness of the strategy and its' effectiveness, it requires that students receive a model of instruction that includes explicit instruction, modeling/thinking aloud, scaffolding, coaching, and independent practice. Throughout each phase of instruction the teacher gradually releases the responsibility for the strategy to the students.

There are benefits in using QAR as a framework for reading comprehension instruction as well as a framework for comprehension strategy use, for teacher, using QAR to frame the questioning activities within the reading cycle guides their modeling of question-asking practices in the before, during and after reading phases (Raphael \& Au, 2005). Furthermore, according to Wilson, et al. (2009: 710) the QAR framework 
was chosen for the professional development initiative because a common practice for students to be asked to respond to questions in the text. QAR gives a framework for thinking about these questions and provide students with the tools and language for identifying the relationships between text and questions. QAR cannot only guide classroom reading discussion but also assist students in becoming more strategic, or metacognitive, in their reading.

In addition, Stahl (2005: 601) states that 'the questions that teachers ask and instruction in QAR or other teacher-led questioning can act as a springboard and a model for critical thinking and complex student generated questions. Teacher-led questioning can be a powerful vehicle in moving text interactions toward higher levels of thinking and critical literacy'.

Using QAR to plan reading comprehension instruction helps ensure that there will not be an over-emphasis of lower-level skills and questions that only require pupils to locate and recall information. It is clear from research that all students need instruction in reading comprehension, especially the kind that focuses on the strategies required to answer and generate challenging questions (Taylor, Peterson \& Rodriguez, 2003 in Raphael \& Au, 2005).

Consequently, by employing QAR, it is hoped that students will be much easier to comprehend the materials of reading since QAR provides them devices to answer questions. Then the strategy is also expected to make the students accustom to both lower- and higher-level questions without being over-emphasis on lower-level questions. In addition, by means of QAR, the students are hoped to be encouraged to think critically. Therefore, it is believed that QAR can promote students' reading comprehension. 


\section{REFERENCE}

Aebersold, Jo Ann \& Field, Mary Lee. (1997). from Reader to Reading Teacher: Issues and Strategies for Second Language Classrooms. Cambridge: Cambridge University Press.

Ajideh, Parviz. (2003). Schema Theory-Based Pre-Reading Tasks: A Neglected Essential in the ESL Reading-Class. The Reading Matrix, 3(1). http://www.readingmatrix.com/articles/ ajideh/article.pdf

Brown, H. Dauglas. (2000). Principles of Language Learning and Teaching. New York: Addison Wesley Longman, Inc.United States of America: Longman.

(2001).Teaching by Principles: An Interactive Approach to Language Pedagogy. United States of America: Longman.

Burn \& Roe \& Ross. (1984). Teaching Reading in Today's Elementary School. USA:Houghton Mifflin Company.

Conner, Jennifer. Instructional Reading Strategy: QAR (Question/Answer Relationship). http://www.Indianna.edu/ 1517/QAR.htm.

Deboer, John J. \&Dallman, Martha. (1966). The Teaching of Reading. USA: Holt, Reinehart and Winston, Inc.

Duke, Nell K. \& Pearson, P. David. (2001). Effective Practices for Developing Reading Comprehension. Professional article. www.nationalgeographic.dom

Elliott, Stephen N. (1999). Educational Psychology: Effective Teaching, Effective Learning, Second Edition International Edition. Singapore: McGraw-Hill Book Co.

G.E.Simanjuntak. (1988). Developing Reading Skills for EFL Students. Jakarta: Depdikbud, Dirjend, Dikti, P2 LPTK.

Grabe, William \&Fredricka L. Stoller. (2001). Reading for Academic Purposes: Guidelines for the ESL/EFL Teacher. United States of America: Heinle\&Heinle, a division of Thomson Learning, Inc. 
Harmer, Jeremy. (2001). The Practice of English Language Teaching Completely Revised and Updated (3.ed.). Essex: Longman.

Harris, A. J. \&Sipay, E.T. (1980). How to Increase Reading Ability.New York. USA: Longman Inc.

Harris, Robert. (2010). Some Ideas for Motivating Students. from http://www. virtualsalt.com

Heilman, Arthur W. (1964). Principle and Practice of Teaching Reading. Columbus, Ohio: Charles E. Merill Books, Inc.

Helping Students Become Motivated Learners. From http://www.ndt-ed.org/TeachingResources/Classroom'Tips/ Motivating Students.htm

Irwin, Joan. Reseach Base for Critical Reading: Differential Instruction Across Genres. From http://www.nationalgeographic.com.au/ngextreme explorer/pdf/ effective practices.pdf.

Nunan, David. (1992). Cooperative Language Learning and Teaching. Cambridge: Cambridge University Press.

(2003). Practical English Language Teaching. New York: Mc. GrawHill.

Nuttal, Christine. (1996). Teaching Reading Skill in a Foreign Language. Heinemann: Heinemann English Language Teaching.

Peng et al. (2007). Impact of Question-Answer-Relationships on Reading Comprehension. A Paper. Singapore: Pei Chun Public School and Marymount Convent. Minister of Education. Retrieved from www3.moe-edu.sg/edumall/rd/alar/ar peichun/ar peichun qar.pdf.

QAR. From http://www.greece.k12.ny.us/instruction/ela/612/Tools/Qar.pdf

Raphael, Taffy E. (1982) Question-answering Strategies for Children. The Reading Teacher. 187-190. 
(1986). Teaching Question Answer Relationship, Revisited. The Reading Teacher, 39(6), 516-522.

Raphael, Taffy E. \& Au, Kathryn. "QAR: Enhancing Comprehension \& Test Taking Across Grades and Content Area." The Reading Teacher 59, 3, (2005).

Raphael, Taffy E. \& Pearson, P. David. "Increasing Students' Awareness of Sources of Information for Answering Questions." American Educational Research Journal 22, 2 (1985): 217-235.

Readence.J.E. (2006). Question-Answer Relationship. Las Vegas: University of Nevada.

$\begin{array}{llll}\text { Reading for } & \text { A } & \text { Purpose. } & \text { From }\end{array}$ www.schools.nsw.edu.au/media/downloads/.../k.../srft_24_25.pdf

Reading Strategies: Scaffolding Students' Interaction with Text, QuestionsAnswer Relationship. from http://www.greece.k12.ny.us/instru ction/ela/6-12/Reading/Reading\%20 strategies/QAR.htm.

Reading for the $21^{\text {st }}$ Century: Adolescent Literacy Teaching and Learning Strategies. Alliance for Excellent Education Journal: Issue Brief. Retrieved 2004.

From http://www.all4ed.org/files/Reading 21stCentury.pdf

Ricards, Jack C. (1996). Reflective Teaching in Second Language Classrooms. New York: Cambridge University Press.

Ricards, Jack C. \& S Roger, Theodore. (2001). Approaches and Method in Language Teaching. Cambridge: Cambridge University press.

Silberstein, Sandra. (1994). Techniques and Resources in Teaching Reading. Oxford: Oxford University Press.

Snow, Cahterine. (2002). Reading for Understanding: Toward an R\&D Program in Reading Comprehension. Santa Monica, CA: RAND.

Stahl, Katherine A. Daugherty. (2004). Proof, Practice, and Promise: Comprehension Strategy Instruction in The Primary Grades. The Reading Teacher, 57(7). 
Urgurhart, Sandy \& Weir, Cyril. (1998). Reading in a Second Language Process, Product and Practice. London: Longman.

William, Eddie. Classroom Reading Through Activating Content-based Schemata. From flrc.hawaii.edu/rfl/PastIssues/rfl41williams.pdf. . (1996).Reading in the Language Classroom. London: Modern English Publication.

Wilson, Nance S, Dana L. Grisham \&Smentana, Linda. (2009). Investigating Content Area Teachers' Understanding of a Content Literacy Framework: A yearlong Professional Development Initiative. Journal of Adolescent \& Adult Literacy, 52(8), http://bama.ua.edu/ jstallwo/bogota08/articles/literacyrodevel.p $\underline{\mathrm{df}}$

Wing, Chan Kam. Portfolio Assessment of Cooperative Learning Groups in Small Classes: Paper presented at the $32^{\text {nd }}$ Annual Conference --- International Association for Educational Assessment. The Hong Kong Institute of Education. From http://www.iaea2006.seab.gov.sg/conference/ download/papers/Portfolio assessment of cooperative learning groups. pdf 